IZA DP No. 5035

Whatever Works: Dualisation and the Service Economy in Bismarckian Welfare States

Werner Eichhorst

Paul Marx

June 2010 


\title{
Whatever Works: \\ Dualisation and the Service Economy in Bismarckian Welfare States
}

\author{
Werner Eichhorst \\ IZA
}

Paul Marx

$I Z A$

\section{Discussion Paper No. 5035 \\ June 2010}

IZA
P.O. Box 7240
53072 Bonn
Germany

Phone: +49-228-3894-0

Fax: +49-228-3894-180

E-mail: iza@iza.org

Any opinions expressed here are those of the author(s) and not those of IZA. Research published in this series may include views on policy, but the institute itself takes no institutional policy positions.

The Institute for the Study of Labor (IZA) in Bonn is a local and virtual international research center and a place of communication between science, politics and business. IZA is an independent nonprofit organization supported by Deutsche Post Foundation. The center is associated with the University of Bonn and offers a stimulating research environment through its international network, workshops and conferences, data service, project support, research visits and doctoral program. IZA engages in (i) original and internationally competitive research in all fields of labor economics, (ii) development of policy concepts, and (iii) dissemination of research results and concepts to the interested public.

IZA Discussion Papers often represent preliminary work and are circulated to encourage discussion. Citation of such a paper should account for its provisional character. A revised version may be available directly from the author. 
IZA Discussion Paper No. 5035

June 2010

\section{ABSTRACT \\ Whatever Works: Dualisation and the Service Economy in Bismarckian Welfare States}

The paper compares employment structures in five Continental welfare states. These countries feature broad similarities in their reliance on a more dualised model of labour market flexibility, particularly in service occupations with low skill requirements. However, a closer look also reveals considerable differences between national patterns of standard and non-standard work. In Germany (and to a lesser extent Austria), marginal part-time provides a fertile ground for low-paid service jobs, as non-wage labour costs are minimised. In France, fixed-term contracts are a flexible and also cheaper alternative to permanent contracts, especially for younger workers. Dutch service sector employers follow an eclectic approach, as can be seen from high shares of self-employed and part-timers, as well as temporary workers. Finally, Belgium has large proportions of very low-skilled, own-account selfemployed and involuntary fixed-term contracts. On the basis of these results, we identify four transformative pathways towards a more inclusive or flexible labour market: growing wage dispersion, defection from both permanent full-time employment as well as from dependent employment, and government-sponsored labour cost reductions.

JEL Classification: J38, J41, J21, J58

Keywords: labour market dualisation, Continental Europe, fixed-term contracts, part-time work, wage dispersion

Corresponding author:

Werner Eichhorst

IZA

P.O. Box 7240

53072 Bonn

Germany

E-mail: eichhorst@iza.org 


\section{Introduction}

This chapter deals with a group of countries that is, in a comparative perspective, generally seen as prime examples of dualised welfare states and labour markets. What makes Continental European or Bismarckian welfare states (i.e. Austria, Belgium, France, Germany and the Netherlands) particularly interesting for the analysis of labour market change and dualisation is that in the 1990s they were still regarded as major cases of institutional inertia and resilience despite structural problems (Esping-Andersen 1996, Pierson 1996). While recent contributions identified surprisingly successful transformations, it is usually argued that overcoming path dependencies came at the cost of new inequalities at the margin of the labour market (Boeri/Garibaldi 2007, Clegg 2007, Eichhorst/Marx 2009, Eichhorst/Hemerijck 2010, Palier/Thelen 2008, Davidsson/Naczyk 2009).

We refer directly to this strand of research by asking exactly which factors set the Continental European cluster apart from other countries and in which way they possibly favour dualisation. Beyond that (and more importantly), it is our intention to identify and explain intra-regime variation with respect to dualisation in the private service sector, an area that is usually seen as the Achilles' heel of Bismarckian welfare states and employment systems (Scharpf 1997). Despite broad similarities, recent developments in particular have revealed major differences across Continental European countries in terms of labour market change and employment patterns. We argue that this variation can be partly explained by institutional legacies. Labour market institutions create different constraints and opportunities for employment relationships in our cases. What we try to understand is how economic actors (employers and job seekers) overcome countryspecific obstacles to job creation and how this contributes to the process of dualisation. This shifts the focus of our analysis away from politically controlled forms of change to creative strategies at the micro-level, e.g. exploiting legal loopholes or 'converting' regulations to conform to new ends.

We restrict our analysis to the private sector and focus on the development in low-skilled work, especially in low-productivity services. It appears that this area of economic activity is particularly exposed to pressures for flexible jobs and, as a consequence, for dualisation at the margin of the labour market, which makes it an interesting object for studies into dualisation.

The article is organised as follows: after presenting the argument, the comparative section provides empirical data on labour market dualisms in our five cases. The idea is to identify and assess the prevailing forms of dualism as well as to explain the diverging patterns by including the general institutional framework. Finally, we suggest an inductively derived typology of labour market dualisms. 


\section{Different responses to a common problem}

As we argue in this chapter, the process of welfare or labour market dualisation should be primarily interpreted from a labour cost perspective. With a considerable degree of simplification, one can say that over the past decades all developed economies have been exposed to a common trend: the growing pressure in favour of differentiation and employment flexibility, particularly at the lower end of labour markets. In the course of globalisation and skill-biased technological change, low-productivity jobs in manufacturing industries have increasingly been put under pressure. At the same time, structural change has affected working conditions. To exploit employment potentials in the service economy, labour market institutions have to be flexible enough to allow for remuneration corresponding to relatively low productivity levels.

How did economies react to this challenge? It may be illustrative to recall Iversen and Wren's (1998) famous 'trilemma of the service economy' in order to understand the implications for the integration of low-skilled workers into the labour market. Since productivity of many workers cannot be improved easily and since neither low employment levels nor increased public spending are sustainable solutions, the pressure to allow for more inequality also increased in traditionally egalitarian societies.

But obviously, inequality can take many different forms, and so does its counterpart, flexibility. Broadly speaking, we have to differentiate according to the scope of flexibility (the whole labour market or only particular segments) and different types of flexibility as identified in the seminal contribution by Atkinson ${ }^{1}$ (1984). The question why different patterns prevail in different countries is at the core of the cross-country variation in the degree of dualisation. In a stylized fashion, one can argue that liberal market economies typically ensure labour market inclusiveness by letting wage levels correspond to productivity, so that inequality is reflected in a dispersed wage scale. In many European economies, this is impeded by institutionalized downward 'rigidities' such as minimum wages and collective bargaining as well as non-wage labour costs and higher reservation wages due to more generous systems of unemployment protection. Together with turnover costs created by employment protection, these institutions render standard employment too expensive for low-skilled work. At the same time, however, already high levels of labour taxation and social security contributions make an expansion of public employment following the Scandinavian trajectory virtually a non-issue.

Moreover, core labour market institutions are not only detrimental to employment creation in the service sector; as we know from the 'new politics' literature, they also create strong path dependencies, as those covered form a non-negligible

\footnotetext{
${ }^{1}$ Including wage flexibility, numerical flexibility and functional flexibility. The latter two can apply to internal or external labour markets. For our purpose, the functional aspect can be neglected, since we focus on a segment which by definition has a limited employability. In addition, internal flexibility is less important for this vulnerable group. In the following, we therefore concentrate on wage and external-numerical flexibility.
} 
constituency against liberalisation (Palier/Martin 2007, Saint-Paul 1996). In this highly constraining and path dependent context, we expect the actual behaviour of economic actors to be an important source of institutional change. Employers and job seekers have various options to circumvent standard labour market regulation because there is some inevitable institutional leeway to create flexible and cheap jobs. 'Bogus' self-employment may be the best example for this. By definition, such indirect solutions to the labour cost problem lead to the creation of labour market segments with inferior job quality (in terms of wages, employment stability or social security coverage). Continental European welfare states, with their strict dismissal regulations and contributory unemployment benefit systems, are 'usual suspects' for this two-tier pattern of flexibility.

How secondary segments are exactly defined (or which type of flexibility prevails) depends on the room to manoeuvre provided by existing institutions. Empirical observations suggest that there is a trade-off between different types of 'cheap labour' (King/Rueda 2008, Maurin/Postel-Vinay 2005); but what explains these differences? From an institutionalist perspective, which road will be taken primarily depends on the malleability of the status-quo. For example, the most straightforward way to achieve flexibility via wages may not be an option if a statutory minimum wage imposes a downward limitation. Yet, alternative types of contracts, say freelance, may provide possibilities for low-wage work. Or temporary contracts - which usually involve a wage penalty as well - help at least to save firing costs. It goes without saying that in real-world labour markets, combinations of different flexibility types exist.

Hence, if one assumes general pressure for more flexibility at the margin of the labour market, the different trajectories of change appear as functionally equivalent solutions to the common problem of boosting demand for low-skilled labour. These solutions lead to different flexibility patterns, but to a larger or lesser degree they all reflect the creative strategies of economic actors and policy-makers to include more heterogeneous workers in the labour market.

\section{Mapping flexibility and dualism}

In the following section, we will present a snapshot of current 'flexibility mixes' and 'dualisms' in the countries under scrutiny. The intention is to show empirically that each case developed a distinct solution to the labour-cost problem in the service sector, which corresponds to a particular form of dualism.

A significant share of jobs in private services are non-standard forms of employment. This includes (marginal) part-time, fixed-term contracts, agency work, freelance and low-wage jobs. To understand why countries predominantly rely on one form of flexible work or another, we have to consider the level of regulation, remuneration and social protection of these segments in comparison to standard contracts. The less qualifications and productivity matter, the more we expect employers to exploit the 'cheapest' available option in terms of labour cost (including adjustment cost, such as severance pay). Hence, the degree of external 
and wage flexibility at the margin will be determined by the configuration of three elements:

- regulation of temporary work vis-à-vis permanent contracts,

- wage setting (i.e. coverage by collective agreements or binding national or agreed minimum wages) and the resulting actual pay distribution,

- incorporation into the social security system and related taxes and social security contributions raised on atypical jobs (particularly marginal parttime and freelance).

To explain the various patterns of labour market dualism in Continental European welfare states, indicators for each of the three domains are presented below. Unfortunately, limitations of EU LFS and EU-SILC data hamper the analysis of complex dynamics and multiple characteristics such as type of job and low pay incidence at the sectoral level. Hence, we supplemented our analysis by national studies and more qualitative work.

Figure 1: Wage dispersion and dismissal protection in the OECD, 2005

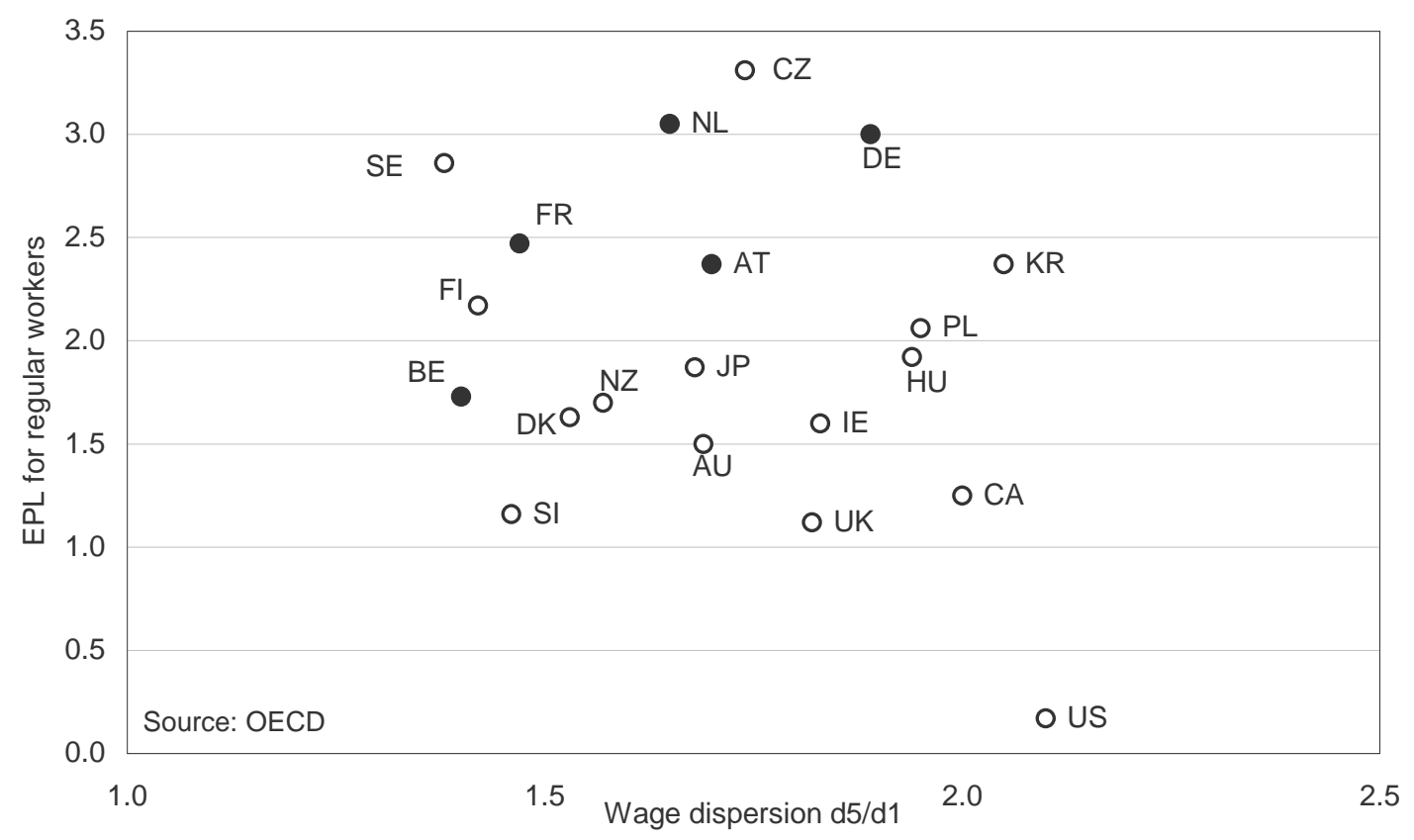

To start with, figure 1 demonstrates that it makes sense to talk of a Continental cluster when we analyse the conditions for cheap and flexible work. If the OECD indicator for the strictness of dismissal protection is plotted against the medianto-low wage dispersion (as an approximation for downward wage rigidities), our cases seem to be quite similar in an international perspective. Belgium deviates somewhat in terms of employment protection, but this follows from the great importance of collective agreements, which are not captured by the indicator. Furthermore, Germany clearly stands out when it comes to wages dispersion, where 
it shows larger values than Australia, Ireland and UK. This notable intra-regime variation will be addressed below in greater detail.

The large similarities between the Continental countries are not necessarily mirrored in employment rates and structures. Figure 2 shows that the overall employment rate is highest in the Netherlands, followed by Austria, Germany, France and Belgium. So the Dutch labour market is more inclusive, but this comes with a larger share of temporary jobs. This is not a general pattern, however, as Austria combines a relatively high employment rate with a large share of permanent employment. On the other side, France features moderate labour market participation despite extensive use of temporary contracts.

Figure 2: Temporary workers and employment rates in the OECD, 2008

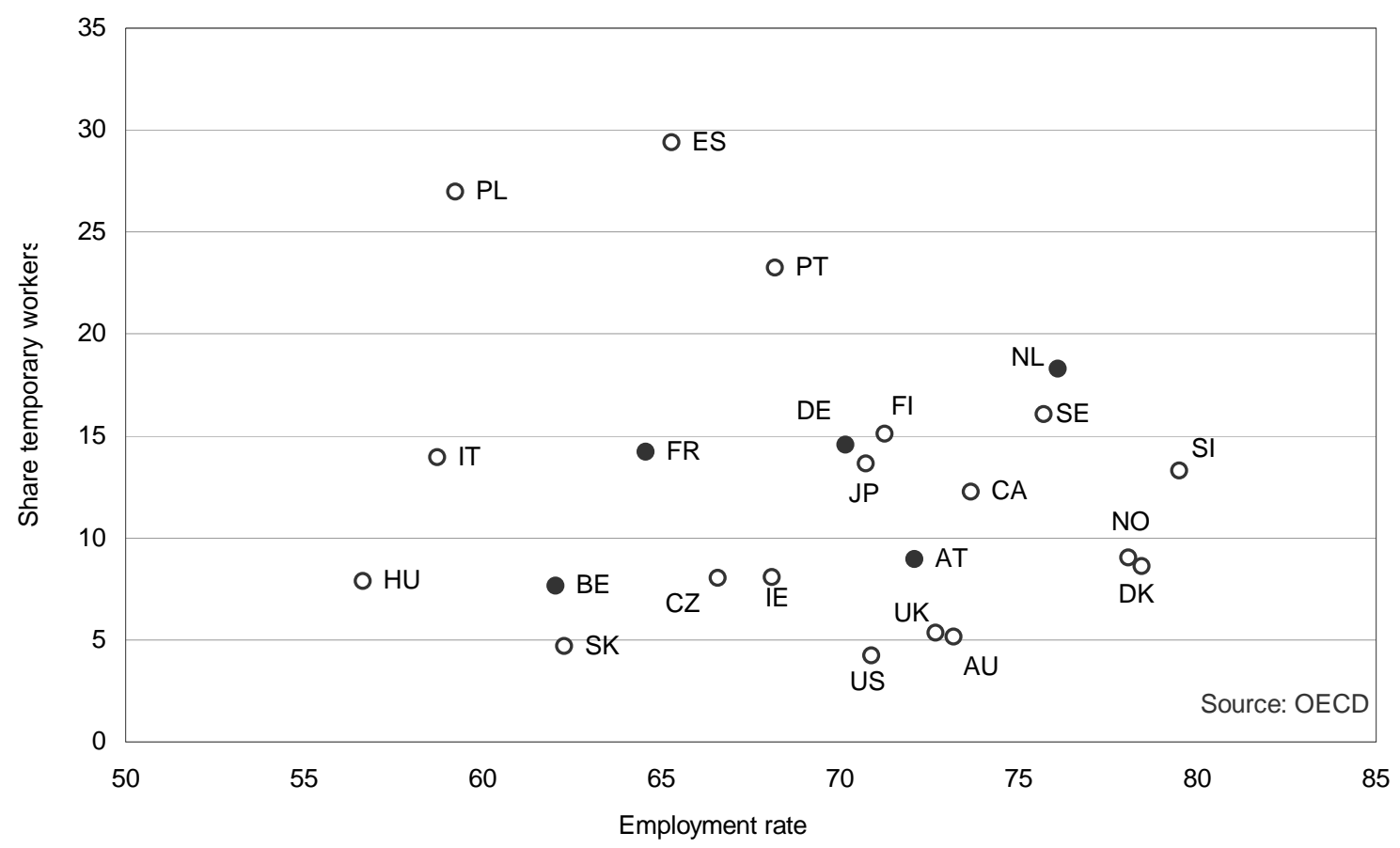

A finer-grained look at employment structures reveals further differences between our cases. In figure 3, data on the distribution of types of jobs across selected occupational groups is shown. The classification is based on Häusermann and Schwander (2009). The figure compares lower service functionaries (LSF), i.e. service occupations with rather low-skill requirements, such as personal and protective ones, mixed service functionaries (MSF), e.g. office clerks, and blue collar jobs. The comparison reveals obvious sectoral cleavages. Low-skilled service jobs are characterised by the largest variation of employment contracts in all countries, especially in Germany, where almost 20 percent work in a marginal part-time job, and the Netherlands. Here, marginal part-time as well as fixed-term contracts are important forms of flexible work (both 15 percent). The latter are quite common in France as well (16 percent). The most favourable structure is found in the Austrian LSF category. While a non-negligible share of 8 percent works marginal part-time, 83 percent hold a permanent contract (full or parttime). One should note, however, that apprentices who typically hold fixed-term 
contracts are excluded from the sample in order to remove the bias of the dual training system in Austria and Germany.

In all countries, the self-employed play a smaller role in services compared to the rest of the economy. However, the EU-LFS data provides neither information on the number of employees nor on income, which would be necessary in order to assess the contribution of self-employment in reducing labour costs (see below).

Figure 3: Types of contract (\%) by sector, 2007
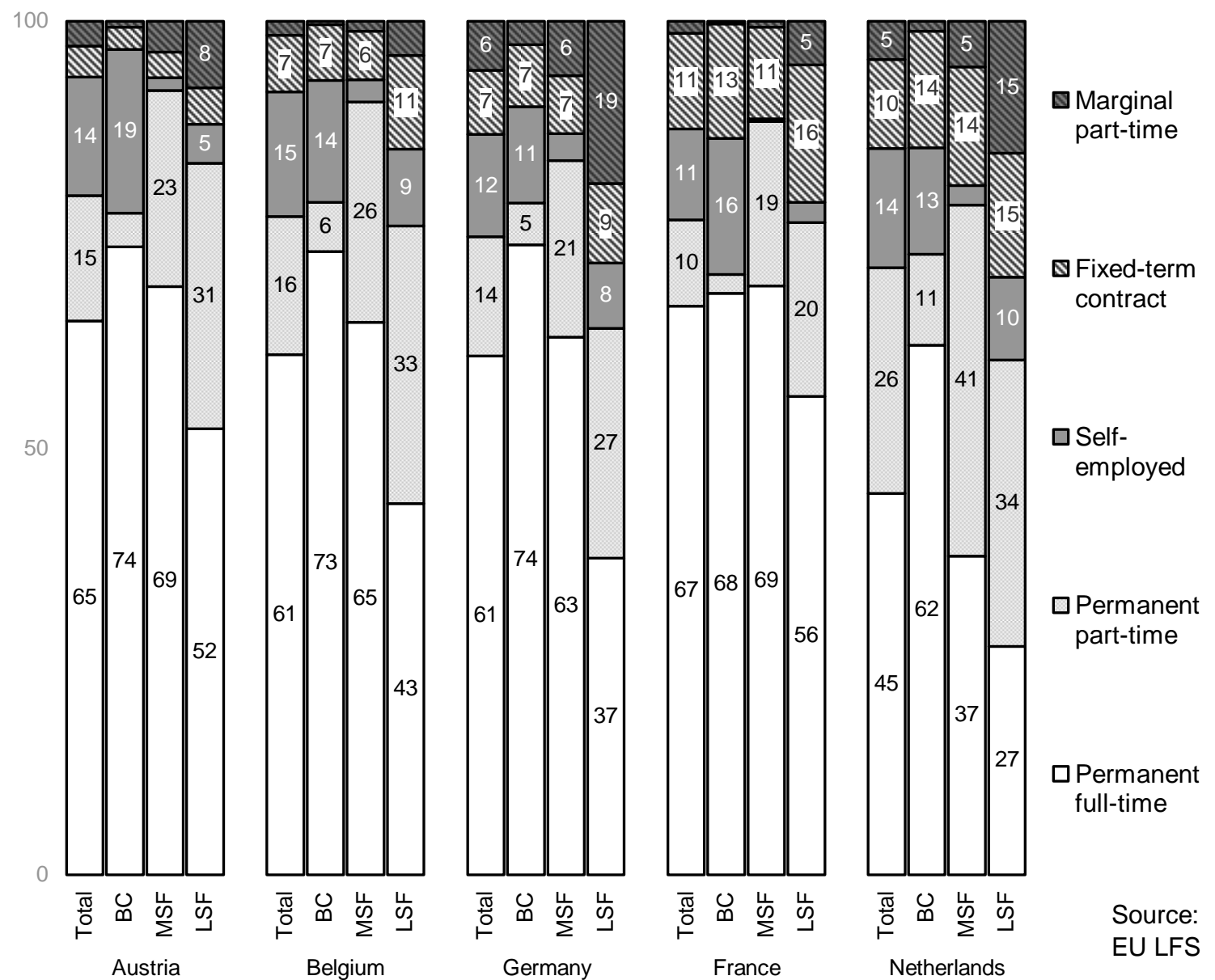

Note: Only values from 5 percent onwards are displayed. The classification is based on ISCO-88 (two digits) and the concept of Häusermann and Schwander (2009). Legend: BC = blue collar (ISCO 61, 71-83, 92, 93), MSF = mixed service functionaries (ISCO 41, 42), LSF = low service functionaries (ISCO 51, 52, 91). Apprentices are excluded.

Finally, figure 4 plots trends over time (the cross-sectional picture deviates somewhat from figure 3 , since here apprentices are included). It shows that the share of temporary contracts in the whole labour market grew in all countries since the mid-1980s, but particularly so in the Netherlands and France (11 and 10 percentage points, respectively). The increase is more modest in Germany (5 percentage points) and Austria (3 percentage points since 1995). In Belgium, the trend is relatively volatile and lacks a clear direction. 
Figure 4: Share of temporary contracts in total dependent employment, 1985-2008

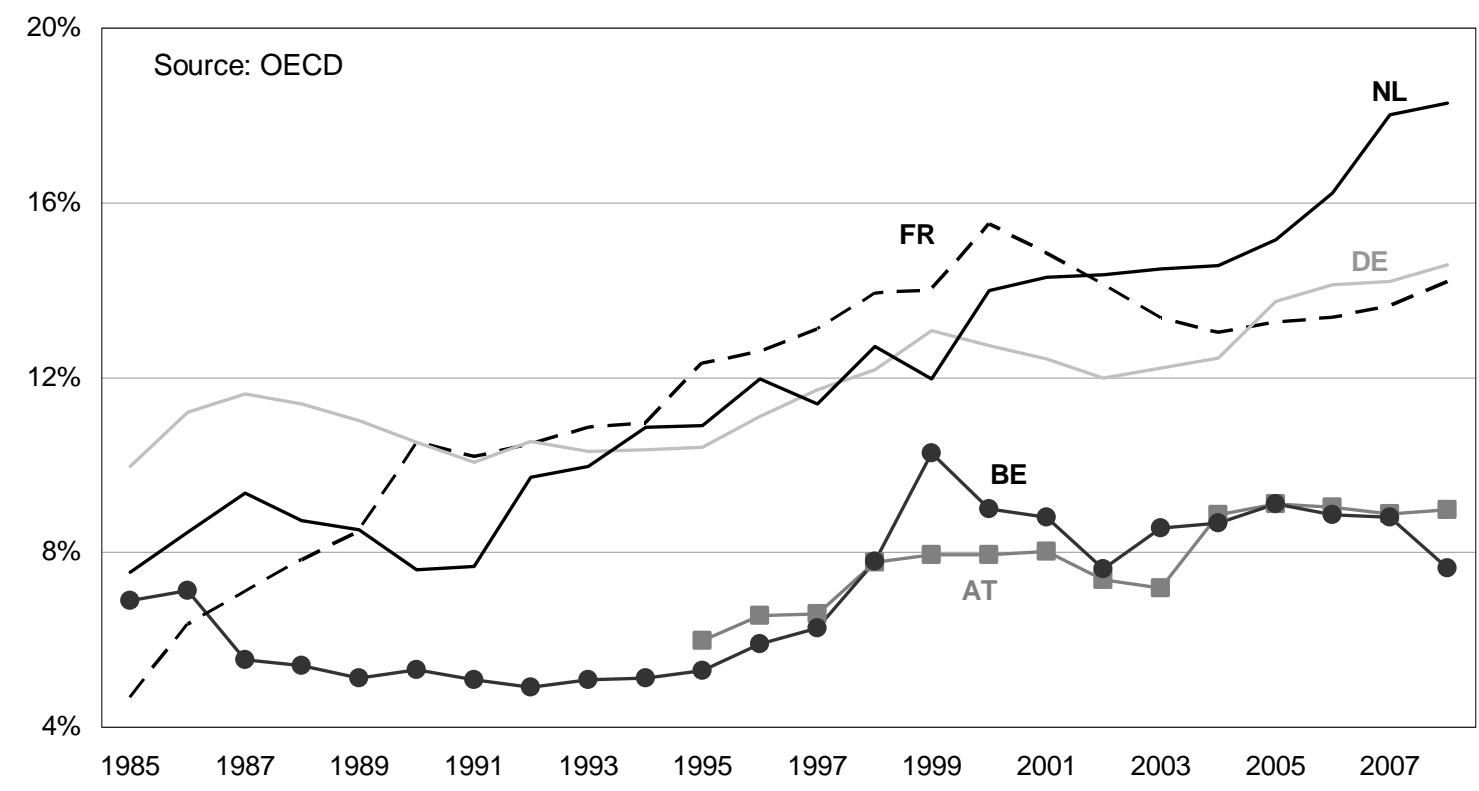

Notwithstanding a broad similarity, a closer look at our cases reveals considerable cross-country variations. The differences are most pronounced in the segment of low-skilled private services, the subject of our study. After this broad overview, the remainder of the section deals with various types of flexible work in more detail. This comprises (1) wage flexibility, (2) temporary work, i.e. fixedterm contracts and agency work, (3) part-time employment, and (4) selfemployment.

\section{Wage flexibility}

Wage flexibility has a pivotal role in our argument, since the straightforward way to facilitate job creation in low-skilled services is to allow for sufficient wage dispersion. What complicates matters is that wage flexibility can be seen as both a dependent and independent variable. That is because restrictions for wages to respond to productivity differentials make the more indirect strategies (which we summarise under the heading of dualisation) necessary in the first place. On the other hand, wage flexibility can be an effect of dualisation if labour market segments are created that are outside the traditional wage setting regime. Although not always possible due to data limitations, we try to disentangle the two. We start with an overview on the flexibility of the standard wages and treat issues of remuneration of flexible jobs in the respective sub-sections. 
Table 1: Selected indicators on wage flexibility

\begin{tabular}{lccccc}
\hline \hline & $\mathrm{BE}$ & $\mathrm{DE}$ & $\mathrm{FR}$ & $\mathrm{NL}$ & $\mathrm{AT}$ \\
\hline \hline Minimum wage as \% of median (2008) & $\begin{array}{c}50.6 \% \\
(-4.9)\end{array}$ & - & $\begin{array}{c}62.7 \% \\
(+6,9)\end{array}$ & $\begin{array}{c}42.8 \% \\
(-9.4)\end{array}$ & - \\
Change since 1990, \% points & $23.4 \%$ & $16.2 \%$ & $29.7 \%$ & $13.8 \%$ & $22.5 \%$ \\
\hline Employer soc. security contributions (2008) & & & & & \\
Collective bargaining coverage (2006) & $96 \%$ & $61 \%$ & $90 \%$ & $84 \%$ & $98 \%$ \\
Overall coverage & $\mathrm{H}$ & $\mathrm{M}$ & $\mathrm{H}$ & - & $\mathrm{H}$ \\
Industry & $\mathrm{H}$ & $\mathrm{L}$ & $\mathrm{H}$ & - & $\mathrm{H}$ \\
Service I & $\mathrm{H}$ & $\mathrm{H}$ & $\mathrm{H}$ & - & $\mathrm{H}$ \\
Service II & & & & & \\
Wage dispersion (decile ratio) 2005 & 1.4 & 1.89 & 1.47 & 1.65 & 1.7 \\
decile 5/1 & $(-)$ & $(+0,28)$ & $(-0,17)$ & $(+0,08)$ & $(-)$ \\
Change since 1990, \% points & & & &
\end{tabular}

Source: OECD; transition rates: European Commission (2009); collective bargaining: Eurofound, EIRO: Industrial Relations Country Profile. Note: Service I = Trade, Repair, Hotels, Restaurants, Logistics and Telecoms, Financial and Business Services. Service II = Public, social and other non-commercial services. VL = very low $(0-20 \%), L=$ low $(26-50 \%), M$ = medium (51-75\%), $\mathrm{H}=$ high $(76-100 \%)$.

Although the results have to be treated with caution, OECD data on wage dispersion reveal significant differences across our cases (for the limitations of international wage data and of the OECD approach in particular, see Lucifora et al. 2005). We include information on the ratio of the median and the first wage decile, since we are interested in how low-skilled workers perform compared to the standard. As noted earlier, Germany in this respect clearly exceeds the levels of the other cases. Moreover, growth of wage inequality since the early 1990s has been particular strong. Table 1 also provides information on the institutional background, which explains why Germany stands out. The data on wage dispersion reflects two crucial institutional differences between the countries. First, collective bargaining is quite weakly developed in market-related services in Germany, as table 1 shows. Coverage (across the economy as well as in commercial services) is much higher in Belgium and Austria as well as in France, where bargaining results are regularly extended to all firms in a sector. Second, cases with general and high minimum wages tend to have narrower wage dispersion. In 2008 , the French SMIC amounted to 63 percent of the median wage, which is by far the most generous level in the OECD and certainly helps to limit wage dispersion. A statutory minimum wage also applies for the Netherlands, however, with a much lower rate (table 1). Belgium and - most recently - Austria have generally binding, collectively agreed minimum wages covering the whole economy. Given a large number of companies outside collective bargaining and the absence of a binding wage floor, it is fair to say that the German institutional setting is the least prepared to contain pressure for wage inequality.

A further important aspect of wage flexibility - particularly in Bismarckian welfare states - is the level of non-wage labour costs. All countries in the sample have insurance-based social security systems, which are partly financed by employer contributions. The problem for low-productivity occupations with remuneration levels close to the minimum wage (as defined by law, collective agreement or implicitly by the benefit system) is that these costs cannot be shifted to the em- 
ployee. Hence, payroll taxes can impede job creation in low-skilled services (Scharpf 1997). Data from the OECD show that all countries have considerable contribution levels (table 1 ). The burden of non-wage labour costs directly explains some severe cases of dualisation. In Austria and Germany, low earnings are exempted from payroll taxes and therewith constitute an indirect solution to the labour cost problem in services (see point 3).

The French case illustrates the effects of a generous minimum wage in combination with high, non-wage labour costs. Because of the existence and the regular increases of the SMIC, France is an exception to the general trend of increasing wage dispersion observed in many European countries. In addition, the widespread extension of collective agreements imposes binding wage rates above the SMIC, also in private services. This contributes to the containment of lowpaid work in services. Nevertheless, there is a persistently high level of employment of low-skilled people in France. This can be explained by massive wage subsidies in the form of reduced social insurance contributions for employment at (or close to) the SMIC rate. This policy was launched in the early 1990s by the Balladur government to offset the labour cost problems generated from minimum wage increases based on political grounds (Jamet 2006). Subsequent governments incrementally expanded the measure, with the effect of a growing gap between the relatively generous take-home pay for low-skilled workers and the actual labour costs for the employer (Pisany-Ferry 2003). Hence, to limit wage dispersion and to counter an erosion of collective bargaining, minimum wages are increased regularly - but part of the cost for creating or maintaining jobs in the low-wage segment has shifted to the public budget. Albeit implying considerable costs, this policy brings about obvious advantages in terms of employment policy and social equity. In particular, subsidisation reduces the employers' need to search for alternative sources of cheap labour and therefore limits wage dispersion. However, besides costliness, subsidised jobs create additional problems: while they are quite stable and most often full time, the subsidy scheme hampers upward mobility. As higher hourly wages imply a disproportionate increase in employers' labour costs, barriers to higher remuneration levels are quite high. This persistence can be seen as one major element of dualisation in the French labour market. A similar policy exists in Belgium, where wage dispersion is also very limited. Here, the 'plan d'embauche' subsidises low-skilled employment by providing reductions of social security contributions for different target groups. Furthermore, publicly subsidised service vouchers have been introduced and gradually expanded.in services delivered to private households in both countries, i.e. a field in which labour cost are of particular concern,

\section{Temporary employment}

As argued by King and Rueda (2008) and Maurin and Postel-Vinay (2005), temporary employment partly compensate as a second-best solution for high labour costs. Fixed-term contracts and agency work reduce turnover costs and usually feature a wage gap to permanent employment, even if individual characteristics are controlled for (Brown/Sessions 2005; evidence for Germany is provided by 
Giesecke 2009, for France by Blanchard/Landier 2002 and for the Netherlands by Zijl 2006). One reason for this could be that equal pay regulation is lacking or not enforced effectively. According to this, temporary contracts should not only be attractive in countries with very strict dismissal protection (France, Germany and the Netherlands in our sample) but in all cases with a labour cost problem.

However, fixed-term contracts can fulfil quite different functions. Besides being a source of external flexibility or cheap labour, they can also serve as a means of personnel policy to screen workers over an extended period of time. In this latter case, the quality of the job and - most importantly - the perspectives of making a transition to a permanent contract can be expected to be best.

Table 2 provides indicators for the use of fixed-term contracts in the five countries. Involuntarily temporary jobs are most frequent in Belgium and France. This suggests that they primarily constitute a secondary segment in the labour market serving as a flexible and cheap buffer. This interpretation is supported by the high share of extremely short durations and - at least for France - by low transition rates to standard employment. Gash (2008) finds that such transitions are significantly less likely in France compared to West Germany. According to calculations based on EU-SILC, only around 15 percent of French workers with a fixed-term contract move on to a permanent job each year. The share is largest in Austria, at almost 50 percent. Here, as in Germany, educational purposes are most prominent. In that sense, fixed-term jobs are more problematic in Belgium and France than they are in Germany, Austria or the Netherlands. Workers are mostly in this segment because they could not find a permanent job. They have relatively short contracts, which makes eligibility to unemployment benefits difficult and (in the French case) opportunities to make a transition to a better job are quite poor. Further striking indicators are the dominance of very short contracts (less than six months) as well as the high share of younger workers in France. Although only 20 percent of fixed-term contracts are used for training, around 50 percent of all temporary workers are younger than 25 years. Hence, fixed-term contracts are predominatly used for younger workers, without involving any educational purpose.

It is interesting to note that France, in contrast to most other neighbours, did not significantly deregulate fixed-term contracts. The French reform process as such was rather inconsistent and, as far as labour law is concerned, not clearly directed at dualisation. The OECD indicator for the strictness of employment protection legislation even shows a slight tightening of regulations for fixed-term contracts between 1985 and 2008, which is against the trend in most of the OECD countries. Armour et al. (2009), who provide an alternative measure, come to a similar result: after a steep increase of regulation in the 1982 'lois Auroux', fixedterm contracts were slightly de- and re-regulated in various steps. They remained, however, at the very high level of the early 1980s. Yet, according to Eurostat, the share of fixed-term contracts in total employment increased from 3 to 14 percent between 1983 and 2008. The fact that fixed-term employment developed into a secondary segment in the labour market despite relatively strong restrictions, points to the importance of non-political dynamics. Clearly the devel- 
opment was affected by regulatory changes; but it also goes back to the way in which these contracts are actually used (and how the use changes over time). The increase of temporary work has to be interpreted against the background of the overall institutional framework. The French procedure for individual dismissals is even stricter than the German one, making alternative contracts particularly attractive. Hence, compared within the national institutional setting, fixed-term contracts, even if heavily regulated, are an important source of external flexibility. This particularly concerns young labour market entrants and formerly unemployed who have difficulties to qualify for a permanent job. By now, there exist a set of temporary and subsidised forms of employment to 'insert' unemployed into the labour market (Barbier/Kaufmann 2008).

Table 2: Selected indicators on fixed-term contracts, 2008

\begin{tabular}{lccccc}
\hline \hline & $\mathrm{BE}$ & $\mathrm{DE}$ & $\mathrm{FR}$ & $\mathrm{NL}$ & $\mathrm{AT}$ \\
\hline \hline OECD Index strictness of regulation & $\begin{array}{c}1.5 \\
\text { Change since 1990, \% points }\end{array}$ & $\begin{array}{c}0.75 \\
(-3.75)\end{array}$ & $\begin{array}{c}4 \\
(-2.75)\end{array}$ & $\begin{array}{c}0.75 \\
(0)\end{array}$ & $\begin{array}{c}1.75 \\
(-0.75)\end{array}$ \\
\hline Share of involuntary contracts & $78,5 \%$ & $24,1 \%$ & $54,8 \%$ & $35,2 \%$ & $12,5 \%$ \\
Change since 1990, \% points & $(+22,4)$ & $(+8,4)$ & $(-)$ & $(-17,9)$ & $(-3)$ \\
\hline Share education or training & $9.9 \%$ & $57.0 \%$ & $20.5 \%$ & $3.3 \%$ & $49.3 \%$ \\
\hline Duration less than 6 months & $49.1 \%$ & $18.4 \%$ & $49.6 \%$ & N.A. & $23.5 \%$ \\
Duration 7-18 months & $30.9 \%$ & $28.7 \%$ & $24.2 \%$ & N.A. & $22.6 \%$ \\
Duration 19-36 months & $8.0 \%$ & $39.5 \%$ & $16.9 \%$ & N.A. & $34.8 \%$ \\
Duration more than 36 months & $11.8 \%$ & $11.3 \%$ & $2.8 \%$ & N.A. & $18.7 \%$ \\
\hline Annual transition rate to permanent job & $38,7 \%$ & $28,5 \%$ & $14,7 \%$ & $22,0 \%$ & $48,7 \%$ \\
(average 2004-2007) & & & & & \\
\hline Share of fixed-term contracts among... & $29.5 \%$ & $56.6 \%$ & $51.5 \%$ & $45.2 \%$ & $34.9 \%$ \\
Young workers (15-24) & $7.0 \%$ & $10.2 \%$ & $11.2 \%$ & $14.2 \%$ & $4.8 \%$ \\
Prime-age workers (25-49) & $3.6 \%$ & $4.7 \%$ & $6.3 \%$ & $6.9 \%$ & $2.7 \%$ \\
Older workers (50-64) & & & & & \\
\hline \hline
\end{tabular}

Source: Eurostat (some data are unreliable and should be interpreted with caution); transition rates: European Commission (2009); EPL: OECD, Venn 2009.

A similar situation can be observed in the Netherlands. Although the country has been praised for its 'flexicurity' approach, in terms of labour law, the country features the typical Continental dual structure. The system of dismissal protection, which either demands ex-ante permissions by an official body or rather high severance pay, is among the strictest in the OECD. Although this legislation has been strongly criticised and although there have been several attempts to change it, liberalising reforms have so far been very modest. The consequence has been a reform process mainly targeted at atypical workers. Evaluations have shown that this led to deteriorating conditions for workers with fixed-term contracts, especially in terms of transition rates.

Although the expansion of fixed-term contracts in the Netherlands clearly has been politically facilitated, initially it also goes back to an uncontrolled dynamic at the micro-level. In the 1990s, strict employment protection gave rise to peculiar practices to circumvent restrictions on fixed-term contracts. At the time, it became common to rely on what was called 'revolving door construction': since consecutive fixed-term contracts were automatically transformed into permanent 
ones, employers hired workers with an expired contract via temporary work agencies for a short time, just to rehire them on another fixed-term contract. This allowed for an extensive use of temporary workers. The flexicurity legislation can be partly seen as reaction to this trend. Thus, it was not only designed to liberalise temporary work but also to counter its uncontrolled use by creative employers (Houwing 2010). Accordingly, the share of involuntary fixed-term contracts has clearly declined since 1990.

In the Belgian LFS sector, fixed-term contracts are less pronounced than in the French or Dutch one. One obvious explanation is the more flexible labour law, which does not create to the same degree incentives for employment outside statutory dismissal protection. However, one should note that collective agreements in Belgium create notable additional barriers for dismissals. This makes fixed-term contracts attractive, and the expiry of these contracts account for more than two thirds of all involuntary separations (Cockx/Van der Linden 2009). And in fact, deregulation has been considerable over the past twenty years. Also in a qualitative sense, one can observe an exacerbated dualism: involuntary contracts have increased dramatically and now approach 80 percent, while educational purposes hardly play a role. As in France, contracts typically are relatively short, which demands even more flexibility from workers. Hence, fixed-term contracts are less common in Belgium but clearly constitute a secondary segment.

This is different in Germany, where fixed-term employment is not a major source of dualisation in private services, although there is a widening regulatory divide between permanent and temporary jobs. About half of all temporary contracts are dual apprenticeships, and a major part of the remaining ones are used as extended probationary periods, mostly for high-skilled labour market entrants. It is fair to say that fixed-term jobs do not provide a major element of duality in the German private sector (Boockmann/Hagen 2006). This also applies to Austria, where the share of involuntary contracts is the lowest, while transition to permanent contracts is relatively common.

Table 3: Selected indicators on agency work

\begin{tabular}{lccccc}
\hline \hline & $\mathrm{BE}$ & $\mathrm{DE}$ & $\mathrm{FR}$ & $\mathrm{NL}$ & $\mathrm{AT}$ \\
\hline \hline Share in total employment (2007) & $2.2 \%$ & $1.6 \%$ & $2.5 \%$ & $2.8 \%$ & $1.5 \%$ \\
Growth number of workers (2004-07) & $27.1 \%$ & $53.6 \%$ & $11.9 \%$ & $48.4 \%$ & $34.3 \%$ \\
OECD Index strictness of regulation (2008) & 3.75 & 1.75 & 3.25 & 1.63 & 1.25 \\
Change since 1990, \% points & $(-0.25)$ & $(-2.25)$ & $(+0.62)$ & $(-1.62)$ & $(0)$ \\
Maximum duration in months & $3-18$ & No & $6-24$ & 38 & No \\
Deviation from equal pay possible & No & Yes & No & Yes & No \\
\hline \hline
\end{tabular}

Source: Eurofound (2009); CIETT; EPL: OECD, Venn 2009.

A second, prominent form of temporary employment is agency work. It has since played a small but crucial role in the five countries. While some countries use it merely as a source of numerical flexibility, but effectively enforce equal pay, others use it in addition as a segment of cheap labour. Therefore, it is important to note that deviations from the equal pay principle are possible in Germany and the Netherlands via collective agreements. It is interesting to see that growth in both 
countries has been particularly dynamic and deregulation most intense. In the Netherlands, collective agreements allow deviation in the first 26 weeks of an assignment, which leads to a wage gap for this group of workers (Houwing 2010). A similar - but probably even more pronounced - tendency can be observed in Germany, where the legal loophole led to collective agreements for agency workers with wages significantly below the standard rates in major manufacturing sectors. Thus, the German development serves as a nice example for dualisation caused by unintended consequences of political reform. Because there has been some unexpected competition between different trade unions in the agency work sector, employers could implement an enormous wage gap to their core workforces. However, this mainly affects manufacturing (Kvasnicka 2008) and therefore is of limited interest for the present study. In the other countries, and particularly in the Netherlands, agency work is strongly focused on services.

\section{Part-time}

In all countries (but least so in France), stocks of part-timers are considerable in low-skilled private services. Yet, it is debateable whether regular part-time provides much cost-saving potential for employers. Regulations such as minimum wages, dismissal protection or social insurance apply to this kind of work as well. It is very often unclear whether low working hours serve the interests of the worker or those of the employer. In the Netherlands, involuntary part-time is virtually non-existent, and in Austria and Belgium it is also very limited. This optimism could be related to a quite favourable treatment by the welfare state: generosity of unemployment insurance for low incomes (67 percent of the average wage) is highest in Belgium (for singles) and the Netherlands (for families). In addition, the Belgian and the Dutch system have a strong redistributive component, resulting in higher replacement rates for low-wage earners (which is true to lesser degree for Austria as well). Although France does not perform too badly in this respect either, the share of involuntary part-time is around a third. This value reflects the fact that women rely much less on part-time than in the countries with a more 'conservative' legacy of female labour market participation and family policies. In France, the provision of child care is more developed than in the other Bismarckian welfare states, and the general orientation of women is more in favour of full-time. Accordingly, the LSF sector is much less dominated by part-time than in each of the four other countries (see also figure 3). In fact, we find more regular full-time employment at the minimum wage or slightly above that level. 
Table 4: Selected indicators on part-time work, 2008

\begin{tabular}{lccccc}
\hline \hline & $\mathrm{BE}$ & $\mathrm{DE}$ & $\mathrm{FR}$ & $\mathrm{NL}$ & $\mathrm{AT}$ \\
\hline \hline Share of involuntary part-time & $14.4 \%$ & $22.8 \%$ & $33.6 \%$ & $4.5 \%$ & $11.2 \%$ \\
Share of part-timers working 1-19h & $43.5 \%$ & $56.9 \%$ & $39.3 \%$ & $57.7 \%$ & $41.3 \%$ \\
Share of low paid jobs among PT (2001) & $16 \%$ & $38 \%$ & $20 \%$ & $34 \%$ & $16 \%$ \\
Ul coverage (earnings threshold) & Yes & $400 €$ & Yes & Yes & $358 €$ \\
\hline Net replacement rates relative to average wage & & & & \\
$67 \%$ : one-earner, two children & $69 \%$ & $81 \%$ & $82 \%$ & $85 \%$ & $73 \%$ \\
67\%: single, no children & $77 \%$ & $61 \%$ & $74 \%$ & $71 \%$ & $55 \%$ \\
67-150\%: one-earner, two children & $27 \%$ & $11 \%$ & $13 \%$ & $27 \%$ & $19 \%$ \\
67-150\%: single, no children & $35 \%$ & $0 \%$ & $5 \%$ & $16 \%$ & $10 \%$ \\
\hline \hline
\end{tabular}

Source: Eurostat (some data are unreliable and should be interpreted with caution); OECD; low pay: Salverda/Mayhew (2009); UI coverage: MISSOC.

Because of the regulatory situation in some of the countries, it is necessary to differentiate between regular and marginal part-time. It is important to note that the tax and benefit treatment of marginal part-time crucially increases options for low-wage work in Germany and Austria. In both countries, employers are largely exempt from social security contributions up to a certain wage threshold (€400 and €366, respectively). Particularly in Germany, marginal part-time work (geringfügige Beschäftigung) has become a typical employment pattern in private services. This development is another example for labour market change that is rather driven by economic actors than by policy-makers.

The exemption of part-time with few weekly hours had been designed initially to reduce the administrative burden of workers with only a marginal or irregular attachment to the labour market. This employment opportunity was of minor importance for a long time, and it was only in the 1990s that it became heavily adopted. This was due to the fact that firms discovered the gap in social insurance coverage and taxation as a possibility to reduce labour costs in low productivity jobs. Also, there is an indirect subsidy of low wages via social insurance. Marginal part-time was and is particularly attractive for married women, since in the German social security system, insurance is provided by the insider status of their spouses. One should note that the reinterpretation of marginal part-time as a source of cheap labour was only possible because Germany lacks an institutional constraint found in many other countries. Private service-sector firms typically operate outside collective bargaining and in the absence of binding minimum wages. Only recently have attempts to introduce statutory minimum wages into service sectors become stronger. This effort has so far been of limited impact.

Such attempts have been more successful in Austria, partly because strongly institutionalised social partnership allowed for a negotiated solution. Similar to Germany, the exemption of marginal part-timers from social insurance facilitated the growth of a flexible (female) labour force segment. However, the low-pay risks in this group are lower than in Germany, and in 2009 a general monthly minimum wage of $€ 1,000$ gross was introduced. Based upon a general political agreement 
of the Grand Coalition with the social partners in 2006, this is being implemented via sectoral collective agreements.

\section{Self-employment}

The problem in interpreting data on self-employment is that this form of employment is obviously not, per se, precarious. It includes, for example, cab drivers as well as factory owners. Comparable data on income are difficult to obtain or to interpret, because many respondents in surveys are reluctant to declare it. To approximate the extent to which self-employment serves a source of cheap labour, we therefore include two further variables. The first one is the number of employees. Own-account self-employed often do not have a strong position in the market. In many cases, they fulfil tasks that could be performed by dependent employees as well. However, as they operate outside wage setting institutions, they potentially have to accept lower wages. They also have to bear the immediate entrepreneurial risk of their economic activity, including fluctuations of income. Thus, not having further employees indicates that self-employment is used as a flexible and cheap type of work. At 9 percent, the share of ownaccount self-employment in total employment is highest in Belgium and only slightly lower in the Netherlands. Self-employment in personal services (LSF) is particularly high in the Netherlands, Belgium and Germany, while it is smaller in Austria and negligible in France (figure 3).

Table 3: Selected indicators on self-employment, 2007

\begin{tabular}{lccccc}
\hline \hline & BE & DE & FR & NL & AT \\
\hline \hline Own-account SE (\% of total employment) & $9 \%$ & $6.1 \%$ & $5.8 \%$ & $8.7 \%$ & $6.8 \%$ \\
Share of low-skilled (LSF only) & $42 \%$ & $12 \%$ & $18 \%$ & $36 \%$ & $17 \%$ \\
Ul coverage & No & Mostly no & No & No & Yes \\
\hline \hline
\end{tabular}

Source: EU-SILC; UI coverage: MISSOC.

Within the group of own-account self-employed, there still is considerable variation, and we have to differentiate between 'necessity start-ups' (of workers who lack alternatives) and 'opportunity start-ups' (which are preferred options over dependent employment) (Schulze Buschoff/Schmidt 2009). As the latter is more plausible for academics, a second interesting variable is the skill composition of the self-employed in LSF. At 42 percent, the share of low-skilled (ISCED 0-2) is extremely high in Belgium and also in the Netherlands (36 percent). An interpretation could be that 'necessity start-ups' are more strongly pronounced in these countries, since self-employment is taken up by many workers with low productivity as an opportunity to enter the labour market.

The only country that tries to balance the high-risk profile of self-employment is Austria, since freelancers are included in unemployment insurance (in Germany, voluntary insurance is possible in some cases). In recent years, however, there is a growing awareness of this problem. Several reforms in Belgium aimed at reducing the disadvantaged status of self-employed workers. This was done by improving access to health insurance, increasing minimum pensions and introducing maternity leave as well as measures to tackle 'bogus' self-employment. How- 
ever, as social security harmonisation mainly relies on tax funding, incorporation into the unemployment system does not seem to be on the agenda (Van Gyes/Vaes 2009).

\section{Different responses to the labour cost problem: an inductive typology}

From the empirical material gathered in this study, we can inductively derive a preliminary typology of flexibilisation trajectories in highly regulated labour markets. The idea is to summarise possible pathways by which exclusive systems (in terms of low-skilled employment) can be transformed into more inclusive ones. With a considerable degree of simplification, we identify four such pathways: increasing wage dispersion, defection from permanent full-time jobs, defection from dependent employment, and government-sponsored flexibility. It goes without saying that combinations are not only possible but inevitable in real-world labour markets.

Wage dispersion. The most straightforward and probably most efficient way to decrease employment barriers is an adaptable wage level in the lower end of the earnings distribution. In our study, Germany and Austria in particular rely on a relatively high dispersion of wages to include low-skilled workers in the labour market. As has been argued above, this approach is contingent on institutional prerequisites. In Germany, the flexible wage setting regime and low bargaining coverage in critical sectors is crucial to understand growing wage inequality. In Austria, even private services are fully incorporated into the collective bargaining process, but a tradition of competitiveness-orientated social partnership and the various institutionalized negotiations have rendered wage rigidity less problematic. Given the institutional context of the other countries, it is rather unlikely that they will follow this path.

Defection from permanent full-time jobs. This path implies the relative growth of either part-time or temporary work. To start with the latter, fixed-term contracts and agency work can be seen as a second-best solution to the labour cost problem in a twofold way. First, they are only necessary because of the inability to conduct a more effective liberalisation of dismissal law. Second, they, in principle, only affect turnover costs and therefore cannot compensate for rigid wages and non-wage labour costs. In practice, however, temporary work typically comes with a wage penalty, because equal pay is not enforced. This points to the crucial question of how such contracts are actually used by individual employers, i.e. as a probation or as a source of flexibility. In this respect, we found very different patterns in our cases. Temporary work can be observed in all service sectors of our analysis, and particularly so in France and the Netherlands. In both cases, there were not only political actions that contributed to the development, but clearly also changing behavioural patterns of employers and job seekers. Thus, it is important to note that this pathway does not presuppose the typical partial deregulation of labour law, although it certainly benefits from it.

Concerning part-time, it is unclear how it generally helps to tackle the labour cost problem. Exceptions are marginal part-time jobs in Austria and Germany that 
bring along major advantages in terms of taxation and non-wage labour costs. Although facilitated by various reforms later on, their initial growth goes back to creative conversion at the micro-level. They therefore are a further example for the non-political dimension of flexibilisation.

Defection from dependent employment. Hiring freelancers for tasks that could have been performed by dependent workers is an effective way to reduce labour costs. There are obvious limitations to this approach: often it is simply not feasible because of the nature of work and also it is located in a legal grey area ("bogus' self-employment). Yet, it is an attractive option in many occupations of the service sector. This is even more so, as this pathway requires no political promotion whatsoever. While the role of self-employed in the liberalisation of European labour markets deserves more empirical research, particularly in terms of income stability, we presented preliminary evidence that they serve as a highly flexible but also insecure segment.

Government-sponsored flexibility. A significant contribution to the reduction of labour costs in the low-skill segments can stem from subsidisation, i.e. in-work benefits, tax breaks, social insurance exemption and so forth. Thus, governments can buy themselves out of the trade-off between labour market efficiency and equality, but they have to accept higher budget deficits. Although such a policy response can be partly observed in all of the countries of our study, Belgium and France are the most pronounced examples of the subsidisation approach.

\section{Conclusions}

The chapter compared employment structures in five Continental welfare states. It showed that these countries feature broad similarities in their reliance on a more dualised model of labour market flexibility. Particularly in service occupations with low skill requirements, economic actors are constrained by institutional barriers to work or hire at low wage levels. In all of our cases more or less efficient strategies emerged to bypass these barriers. As we have shown, the consequence of this development is a trend towards more labour market dualism. In this sense, each case has its 'skeleton in the closet'. However, if one looks closer, there are also considerable differences between the national patterns of standard and non-standard work. In Germany (and to a lesser extent Austria), marginal part-time provides fertile ground for low-paid service jobs, as non-wage labour costs are minimised. In France, fixed-term contracts are a flexible and also cheaper alternative to permanent contracts, especially for younger workers. Dutch service sector employers follow an eclectic approach, as can be seen from high shares of self-employed and part-timers, as well as temporary workers. Finally, Belgium has large proportions of very low-skilled, own-account selfemployed and involuntary fixed-term contracts. On the basis of these results, we identified four transformative pathways towards a more inclusive or flexible labour market: growing wage dispersion, defection from both permanent full-time employment as well as from dependent employment, and government-sponsored labour cost reductions. 
As we argue, intra-regime variation can be best understood if country-specific institutional constraints are included in the analysis as well as the creative (and destructive) behaviour of economic actors to overcome such constraints. We presented some anecdotal and tentative evidence pointing to the importance of micro-level dynamics for the process of dualisation. To investigate how patterns of institutional defection and compliance affect labour market change will be a useful task for future research.

\section{References}

Armour, John/Deakin, Simon F./Lele, Priya P./Siems, Mathias (2009): How do Legal Rrules Evolve? Evidence from a Cross-country Comparison of Shareholder, Creditor and Worker Protection, American Journal of Comparative Law, 57: 579-630.

Atkinson, John (1984): Flexibility, Uncertainty and Manpower Management. IMS Report 89, Institute of Manpower Studies.

Barbier, Jean-Claude/Kaufmann, Otto (2008): The French Strategy Against Unemployment: Innovative but Inconsistent, in: Eichhorst, Werner/Kaufmann, Otto/KonleSeidl, Regina (eds.): Bringing the Jobless into Work? Experiences with Activation Schemes in Europe and the US. Berlin: Springer, 69-120.

Blanchard, Olivier/Landier, Augustin (2002): The Perverse Effects of Partial Labour Market Reform: Fixed-Term Contracts in France, Economic Journal, 112(480), 214244.

Boeri, Tito/Garibaldi, Pietro (2007): Two Tier Reforms of Employment Protection: A Honeymoon Effect?, Economic Journal, 117(521), 357-385.

Boockmann, Bernhard/Hagen, Tobias (2006): Befristete Beschäftigungsverhältnisse: Brücken in den Arbeitsmarkt oder Instrumente der Segmentierung, ZEW Wirtschaftsanalysen 80.

Brown, Sarah/Sessions, John (2005): Employee Attitudes, Earnings and Fixed-Term Contracts: International Evidence, Review of World Economics, 141(2), 296-317.

Clegg, Daniel (2007): Continental Drift: On Unemployment Policy Change in Bismarckian Welfare States, Social Policy and Administration, 41(6), 597-617.

Cockx, Bart/Van der Linden, Bruno (2009): Flexicurity in Belgium: A Proposal Based on Economic Principles, IZA Policy Paper 9.

Davidsson, Johan/Naczyk, Marek (2009): The Ins and Outs of Dualisation: A Literature Review, RECWOWE Working Paper 2.

Eichhorst, Werner/Hemerijck, Anton (2010): Welfare and Employment: A European Dilemma?, in: Alber, Jens/Gilbert, Neil (eds.): United in Diversity? Comparing Social Models in Europe and America, Oxford: OUP, 201-236.

Eichhorst, Werner/Marx, Paul (2009): Reforming German Labor Market Institutions: A Dual Path to Flexibility, IZA Discussion Paper 4100.

Esping-Andersen, Gøsta (1996): Welfare States in Transition: Social Security in the New Global Economy, London: Sage. 
Gash, Vanessa (2008): Bridge or Trap? Temporary Workers' Transitions to Unemployment and to the Standard Employment Contract, European Sociological Review, 24(5), 651-668.

Giesecke, Johannes (2009): Socio-Economic Risks of Atypical Employment Relationships: Evidence from the German Labour Market, European Sociological Review, 25(6), 629-646.

Häusermann, Silja/Schwander, Hanna (2009): Identifying Outsiders across Countries: Similarities and Differences in the Patterns of Dualisation. Recwowe Working Paper 09/2009.

Houwing, Hester (2010): A Dutch Approach to Flexicurity? Negotiated Change in the Organization of Temporary Work, Amsterdam: University of Amsterdam.

Iversen, Torben/Wren, Anne (1998): Equality, Employment, and Budgetary Restraint: The Trilemma of the Service Economy, World Politics, 50(4), 507-546.

Jamet, Stéphanie (2006): Improving Labour Market Performance in France, OECD Economics Working Paper 504.

King, Desmond/Rueda, David (2008): Cheap Labor: The New Politics of 'Bread and Roses' in Industrial Democracies, Perspectives on Politics, 6(2), 279-297.

Kvasnicka, Michael (2008): Does Temporary Help Work Provide a Stepping Stone to Regular Employment?, NBER Working Paper 13843.

Lucifora, Claudio/McKnight, Abigail/Salverda, Wiemer (2005): Low-wage employment in Europe: a review of the evidence, Socio-Economic Review 3(2), 259-292.

Maurin, Eric/Postel-Vinay, Fabien (2005): The European Job Security Gap, Work and Occupations, 32(2), 229-252.

OECD (2009): Taxing Wages 2007-2008, Paris: OECD.

Palier, Bruno/Martin, Claude (2007): Editorial Introduction. From "a Frozen Landscape" to Structural Reform: The Sequential Transformation of Bismarckian Welfare Systems, Social Policy and Administration, 41(6), 535-554.

Palier, Bruno/Thelen, Kathleen (2008): Dualizing CMEs: Flexibility and Change in Coordinated Market Economies, presented at the 16th Conference of the Council for European Studies, 6-8 March 2008: Chicago.

Pierson, Paul (1996): The New Politics of the Welfare State, World Politics, 48(2), 143179.

Pisani-Ferry, Jean (2003): The Surprising French Employment Performance: What Lessons?, CESifo Working Paper 1078.

Saint-Paul, Gilles (1996): Exploring the Political Economy of Labour Market Institutions, Economic Policy, 23, 265-315.

Salverda, Wiemer/Mayhew, Ken (2009): Capitalist Economies and Wage Inequality, Oxford Review of Economic Policy, 25(1), 126-154.

Scharpf, Fritz (1997): Employment and the Welfare State: A Continental Dilemma, MPIfG Working Paper 97/7. 
Schulze Buschoff, Karin/Schmidt, Claudia (2009): Adapting Labour Law and Social Security to the Needs of the 'New Self-Employed': Comparing the UK, Germany and the Netherlands, Journal of European Social Policy, 19(2), 147-159.

Van Gyes, Guy/Vaes, Tine (2009): Belgium: Self-Employed workers, http://www.eurofound.europa.eu/comparative/tn0801018s/be0801019q.htm.

Venn, Danielle (2009): Legislation, Collective Bargaining and Enforcement: Updating the OECD Employment Protection Indicators, OECD Social, Employment and Migration Working Papers 89.

Zijl, Marloes (2006): Economic and Social Consequences of Temporary Employment, http://www.seo.nl/assets/binaries/publicaties/media/2006/proefschriftmarloeszijl.pdf 